LANSDOWn R.V.2013.Luroniumnatans. The IUCN Red List of threatened species 2013:e.T162134A5547543. http://dx.doi.org/10.2305/IUCN.UK.2011-1.RLTS.T162134A5547543.en (dostęp: 13.11.2019).

RosADZIŃSKI S. 2014. Raport z monitoringu gatunków i siedlisk przyrodniczych prowadzonego w latach 2013-2014. Generalny Inspektorat Ochrony Środowiska. http://siedliska.gios.gov.pl/images /pliki_pdf/ wyniki/2013-2014/dla_roslin/Elisma-wodna-Luronium-natans.pdf (dostęp: 03.12.2019).

RozPorZĄDZENIE Ministra Środowiska z dnia 9 października 2014 r. w sprawie ochrony gatunkowej roślin (Dz. U. 2014, poz. 1409).

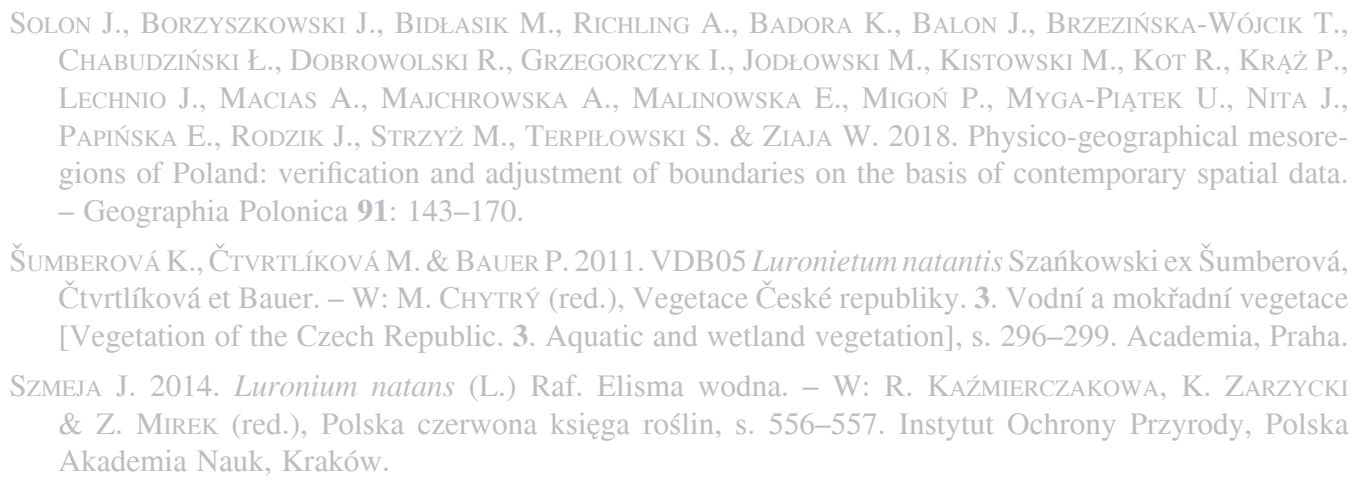

RAFAŁ ChMARA i Emilia ReKowsKa, Katedra Ekologii Roślin Uniwersytetu Gdańskiego, ul. Wita Stwosza 59,80-308 Gdańsk, Polska; e-mail: rafal.chmara@.ug.edu.pl

Wptynęto: 29.01.2020 r.; przyjęto do druku: 24.11.2020 r.

DOI: https://doi.org/10.35535/ffgp-2020-0058

\title{
Nowe stanowisko Bromus secalinus (Poaceae) w Polsce środkowej
}

Rodzaj Bromus L. (stokłosa) obejmuje około 150 gatunków z rodziny Poaceae, rozpowszechnionych w biomach klimatu umiarkowanego półkuli północnej, jak również w wyższych pasmach górskich strefy międzyzwrotnikowej (FEDOROV 1974; HulteN \& FRIES 1986).

Gatunkiem typowym jest Bromus secalinus L. (stokłosa żytnia), znany też pod wieloma nazwami ludowymi, np. kostrzeba, kłosówka polna czy stokłosa kostrzewa. Jest to jednoroczna (sporadycznie dwuletnia), ozima, rzadziej jara, kępkowa trawa o prostych wzniesionych źdźbłach, podzielonych na 5-7 międzywęźli. Charakteryzuje się nagimi, rzadko tylko słabo owłosionymi pochwami liściowymi, luźno owłosionymi blaszkami liści oraz kwiatostanem, a następnie owocostanem w formie wielostronnej wiechy o szorstkich gałązkach. Najdłuższe z nich kończą się 3-5 kłoskami, krótsze jednym lub dwoma. Kłosek pod względem wielkości przypomina nieco pojedynczy ziarniak żyta. Przed kwitnięciem wiecha wznosi się, po zapyleniu luźno zwisa. Jeden osobnik zawiązuje około 1300-1500 podłużnych, brązowych ziarniaków, przyrośniętych do plewki górnej (FALKOwSKI 1982; NowaK \& NowaK 2006). 
W Polsce Bromus secalinus uznaje się za archeofita, a zarazem za porzuconą roślinę uprawną (ang. lost crop). W starożytności i średniowieczu niekiedy celowo siano ją jako zboże i próbowano uszlachetnić (LiTYŃSKA-ZAJĄC 2007; Woch 2012). Próbę wyhodowania odmian uprawnych kontynuowano m.in. w Instytucie Uprawy, Nawożenia i Gleboznawstwa w Gorzowie Wielkopolskim w latach 50. XX w. (FALKOwsKI 1982). Począwszy od lat 70. XX w. stokłosę żytnią uważano za gatunek ginący i wymagający czynnej ochrony w postaci agrorezerwatów (WARChOLIŃSKA 1981, 1994; CIOSEK \& SKRZYCZYŃSKA 1997; NOWAK \& NowAK 2006). Na ogólnopolskiej „,czerwonej liście” przypisano jej wówczas nawet kategorię gatunku narażonego na wyginięcie - V (ZARZYCKI \& SZELĄG 2006; ZAJĄC i in. 2009). Obecnie stokłosa żytnia znowu staje się lokalnie pospolita, głównie jednak na południu i wschodzie kraju (KORNIAK \& DYNOwsKi 2011; SKRAJNA i in. 2012). Zwalcza się ją tam, podobnie jak w Kanadzie i USA, jako uciążliwy chwast zbóż ozimych, odpowiedzialny za straty do 30\% plonu, coraz odporniejszy na graminicydy (Koscielny i in. 1990, 1991; STONE i in. 2006). Natomiast w centrum oraz na zachodzie Polski stanowisk B. secalinus wciąż jest wyraźnie mniej (NowAK i in. 2003; DAJDOK \& WuCZYŃSKI 2008; BomAnOWSKA 2010; KĄCKI i in. 2011; WęGRZYNEK \& NOWAK 2013; ZAJĄC \& ZAJĄC 2014).

W związku z tym interesujące jest monitorowanie nowych stanowisk Bromus secalinus, zarówno z perspektywy rolniczej, jak i botaniki konserwatorskiej. Powodów ponownej ekspansji gatunku upatruje się w uproszczeniach płodozmianu, zmianach klimatu, ekologizacji rolnictwa (stosowaniu bardziej selektywnych, słabiej działających pestycydów), ale i szybkiej koewolucji stokłosy ze zbożami ozimymi oraz innymi gatunkami segetalnymi (STONE i in. 2006; KorNiAK \& DyNOWSKI 2011; SKRAJNA i in. 2012).

W czerwcu 2020 r. stwierdzono nowe stanowisko Bromus secalinus w Ziąbkach (gm. Bolimów, na granicy woj. mazowieckiego i łódzkiego), gdzie obserwowano około 200 kęp rosnących na brzegu pola pszenicy ozimej. Charakterystykę stanowiska przedstawia poniższe zdjęcie fitosocjologiczne. Nazewnictwo gatunków roślin naczyniowych przyjęto za Mirkiem i in. (2002).

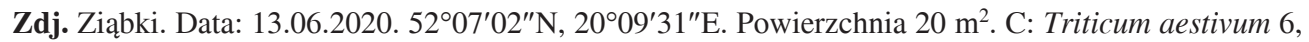
Bromus secalinus +, Apera spica-venti 1, Avena fatua $\mathrm{r}$, A. sterilis $\mathrm{r}$, Papaver rhoeas,+ . argemone $\mathrm{r}$, Centaurea cyanus + , Persicaria hydropiper $\mathrm{r}$.

Zdrowy wygląd oraz obfite owocowanie dostrzeżonych okazów Bromus secalinus sugerują możliwość dalszego trwania nowo odkrytej populacji, jak również zachwaszczenia okolicznych pól. Nasiona okazów z Ziąbek zostały zdeponowane w kriobanku nasion Polskiej Akademii Nauk Ogrodu Botanicznego - Centrum Zachowania Różnorodności Biologicznej w Warszawie-Powsinie. Wyhodowane podczas testów okazy stokłosy żytniej będą prezentowane w Kolekcji Warzyw i Archeofitów PAN OB. CZRB.

Summary. New locality of Bromus secalinus (Poaceae) in central Poland. A new locality of Bromus secalinus (Poaceae) in central Poland is given. About 200 Bromus secalinus tufts were observed at a previously unknown locality in Ziąbki village (Bolimów municipality, Łódź Province) in a wheat field, mostly close to the edge of the field. Plants were healthy and abundantly fruiting. 


\section{LITERATURA}

Bomanowska A. 2010. Threat to arable weeds in Poland in the light of national and regional red lists. - Plant Breeding and Seed Science 61: 55-74.

CioseK M. T. \& SKRZYCZYŃSKA J. 1997. Bromus arvensis and B. secalinus (Poaceae) in the Mazowsze and Podlasie regions (Poland). - Fragmenta Floristica et Geobotanica 42(2): 339-348.

DAJDOK Z. \& WuCZYŃSKI A. 2008. Alien plants in field margins and fields of southwestern Poland. - Biodiversity: Research and Conservation 9(10): 19-33.

FALKowsKi M. (red.). 1982. Trawy polskie. s. 565. Państwowe Wydawnictwo Rolnicze i Leśne, Warszawa.

FEDOROV R. V. 1974. Flora Partis Europaeae URSS. 1. s. 180. Izdatielstvo Nauka, Leningrad.

Hultén E. \& Fries M. 1986. Atlas of North European vascular plants: north of the Tropic of Cancer 1-3. s. 498. Koeltz Scientific Books, Königstein.

KąCKi Z., SzCŹ̨̧́NIAK E. \& CZARnieCKa M. 2011. Bromus secalinus (Poaceae) na Dolnym Śląsku - występowanie i zagrożenia. - Seed 61: 85-92.

Korniak T. \& Dynowski P. 2011. Bromus secalinus (Poaceae) - zanikający czy rozprzestrzeniający się chwast upraw zbożowych w północno-wschodniej Polsce? - Fragmenta Floristica et Geobotanica Polonica 18(2): 341-348.

Koscielny J., Peeter T., Solie J. \& Solomon S. 1990. Effect of wheat (Triticum aestivum) row spacing, seedling rate, and cultivar on yield loss from cheat (Bromus secalinus). - Weed Technology 4 : $487-492$.

Koscielny J., Peeter T., Solie J. \& Solomon S. 1991. Seeding date, seeding rate and row spacing affects wheat (Triticum aestivum) and cheat (Bromus secalinus). - Weed Technology 5: 707-712.

LiTYŃSKA-ZAJĄC M. 2007. Early Neolithic agriculture in south Poland as reconstructed from archaeobotanical plant remains. - W: S. Colledge \& J. Conolly (red.), The origins and spread of domestic plants in southwest Asia and Europe, s. 315-326. Left Coast Press, Walnut Creek, CA.

Mirek Z., PięKoś-Mirkowa H., ZająC A. \& ZająC M. 2002. Flowering plants and pteridophytes of Poland. A checklist. - W: Z. MireK (red.), Biodiversity of Poland. 1, s. 442. W. Szafer Institute of Botany, Polish Academy of Sciences, Kraków.

Nowak A., NowaK S. \& SpaŁeK K. 2003. Red list of vascular plants of Opole Province. - Nature Journal - Opole Scientific Society 36: 5-20.

NowaK S. \& NowaK A. 2006. The synanthropodynamic state of Bromus secalinus L. in the Opole Silesia (SW Poland). - Časopis Slezského zemského muzea, Série A, Vědy přírodní 55: 193-200.

SkRajna T., Kubicka H. \& RzYMOwSKa Z. 2012. Phenotypic variation in relation to seed storage protein polymorphism in Bromus secalinus L. (Gramineae) populations from north-eastern Poland. - Polish Journal of Ecology 60(1): 41-55.

Stone J., Peeper T. \& Stone A. 2006. Rotational cropping systems to reduce cheat (Bromus secalinus) densities. - Weed Technology 20(2): 445-452.

WARCHOLIŃSKA A. U. 1981. Stan i zagrożenie niektórych gatunków chwastów polnych z rodziny Gramineae w środkowej Polsce. - Łódzkie Towarzystwo Naukowe, Sprawozdania z Czynności i Posiedzeń Naukowych 31: 1-8.

WarcholińSKa A. U. 1994. List of threatened segetal plant species in Poland. - W: W. MochnackÝ \& A. TERPó (red.), Antropization and environment of rural settlements. Flora and vegetation. Proceedings of International Conference, s. 206-219. Sátoraljaújhely.

WęGrzynek B. \& Nowak T. 2013. Bromus secalinus (Poaceae) na Wyżynie Śląskiej - tendencje dynamiczne w świetle 17 lat obserwacji. - Fragmenta Floristica et Geobotanica Polonica 20(2): 259-266. 
Woch M. 2012. Antropofity znalezione w trakcie badań archeobotanicznych średniowiecznego Krakowa.

- W: A. MuelLer-BiENIEK (red.), Rośliny w życiu codziennym mieszkańców średniowiecznego Krakowa, s. 185-209. Instytut Botaniki im. W. Szafera PAN, Kraków.

ZAJAC M. \& ZAJAC A. 2014. Survival problems of archaeophytes in the Polish flora. - Biodiversity: Research and Conservation 35(1): 47-56.

ZAJĄC M., ZAJĄC A. \& TOKARSKA-GUZIK B. 2009. Extinct and endangered archaeophytes and the dynamics of their diversity in Poland. - Biodiversity: Research and Conservation 3: 17-24.

Zarzycki K. \& Szeląg Z. 2006. Red list of the vascular plants in Poland. - W: Z. MireK, K. Zarzycki, W. Wojewoda \& Z. SzeląG (red.), Red list of plants and fungi in Poland, s. 11-20. W. Szafer Institute of Botany, Polish Academy of Sciences, Kraków.

Adam KaPler, Zakład Botaniki Konserwatorskiej, Polska Akademia Nauk Ogród Botaniczny - Centrum Zachowania Różnorodności Biologicznej w Powsinie, ul. Prawdziwka 2, 02-973 Warszawa, Polska; e-mail: a.kapler@obpan.pl

Wptynęto: 04.08.2020 r.; przyjęto do druku: 29.12.2020 r.

DOI: https://doi.org/10.35535/ffgp-2020-0059

\section{Sparganium angustifolium i S. minimum (Sparganiaceae) w Tatrach - problemy z identyfikacją gatunków}

Dotychczas okazy Sparganium L., oznaczane jako S. angustifolium F. Michx., znaleziono w Tatrach na kilku stanowiskach, zarówno na Słowacji, jak i w Polsce. We wszystkich przypadkach były to osobniki płonne.

Celem pracy była analiza wszystkich dostępnych danych dotyczących stanowisk Sparganium angustifolium w Tatrach. W tym celu prześledzono literaturę dotyczącą tematu (od pierwszego doniesienia o wystąpieniu tego gatunku na terenie Tatr) oraz dokładnie obejrzano wszystkie okazy zielnikowe w zielnikach: Instytutu Botaniki UJ (KRA), Instytutu Botaniki im. W. Szafera PAN (KRAM) oraz w zielniku Z. Radwańskiej-Paryskiej przechowywanym w Ośrodku Dokumentacji Tatrzańskiej Tatrzańskiego Parku Narodowego. Okazy zielnikowe pochodzące z tatrzańskich stanowisk porównano z materiałem obserwowanym in situ (w Toporowym Stawie Wyżnym) oraz innymi okazami zielnikowymi S. angustifolium i S. minimum zgromadzonymi w krakowskich zielnikach (KRA i KRAM).

Sparganium angustifolium (jeżogłówka pokrewna), gatunek na terenie Polski zagrożony wyginięciem (EN - KAŹMIERCZAKOWA i in. 2016), jest rzadkim reliktem glacjalnym o zasięgu cyrkumborealnym (HultéN \& FrIES 1986). W Europie jego zasięg obejmuje Półwysep Skandynawski, Wielką Brytanię i Islandię, bardziej na południe występuje na oderwanych stanowiskach, znajdujących się głównie w górach, m.in. w Alpach i Karpatach. Na terenie Polski rośnie w jeziorach Pomorza Zachodniego (SzMEJA 2014) oraz na izolowanym stanowisku w Tatrach, gdzie po raz pierwszy odnalazł go Krupa, po słowackiej stronie Tatr w Pośrednim Rohackim Stawie. Znalezisko to potwierdził Kotula, jednak ze względu na obecność jedynie okazów płonnych nie był pewny poprawności oznaczenia 